\title{
THE INFORMATION REVOLUTION AND POST-MODERN WARFARE
}

\author{
Steven Metz, Armed Conflict in the 21st Century: The Information \\ Revolution and Post-Modern Warfare (Carlisle, Barracks, PA: Strategic \\ Studies Institute, USAWC, April 2000). Available online at \\ http://carlisle-www.army.mil/usassi/ssipubs/pubs2000/conflict/conflict.pdf
}

$\mathrm{I}_{\mathrm{t}}^{\mathrm{t}}$ $\mathrm{t}$ is widely accepted that the advancement of communications and information technologies and their implementation by the military changes the nature of warfare. The consistent development of capabilities to find your enemy faster than he finds you, to decide quickly on a course of action, to precisely hit the enemy while limiting collateral damage, and to assess the results of your action, brings a new quality to warfare. Therefore, when expansive introduction of IT is combined with adequate organizational adaptation and doctrinal changes, students of warfare usually speak about "revolution in military affairs."

In his monograph Dr. Metz expands the treatment of 'speed' and 'precision'. He examines strategic speed as equally important to success as the IT-based tactical and operational speed. Strategic speed requires not only mobility and readiness of the military, but also faster political decision-making. Readiness, mobility, airlift and sealift capabilities do not substitute for time consumed by consensus building. Regarding precision, thinking on the revolution in military affairs has so far addressed mostly its physical aspect, i.e., the ability to hit a target with great accuracy from a safe distance and to achieve precisely the desired physical effect. What is more important for the military strategist and commander, however, is to think in terms of psychological precision - to aim at attaining desired attitudes, beliefs, and perceptions both of enemy and observers.

On strategic level, this study of the effects of information revolution is not limited to technological transformation, computer viruses, attacks on commercial communications infrastructure and other potential manifestations of strategic information warfare. Rather, the author studies more broadly the strategic significance of the information revolution in terms of probable 'combatants,' available means and responses, and measures of success. Dr. Metz defines three types 
of war - 'formal,' 'informal,' and 'gray area' war, and focuses the reader's attention on the complexity of the concept of asymmetry in future warfare.

The author admits that for the near future the US military may be the only state actor in post-modern warfare. Nevertheless, it may need to reassess basic defense planning assumptions. Particularly, regarding gray area wars, the creation of American national gendarmerie may be justified. In alliance with similar security forces of other states, it would operate more effectively against gray area enemies in an interconnected security environment and global economy. Likewise, nations may be better prepared for post-modern warfare even without sustaining large, peacetime military. Corporate armies and intelligence services may fill in the ranks in times of need. The military thinkers, however, should address in advance related new realms of strategy, policy and legitimacy.

Several other ideas in this monograph pose intellectual challenges to force planners. For example, Dr. Metz suggests that current division of the military in army, navy, and air force may not be adequate a few decades from now. More appropriate may be to organize the military along types of conflict. Another example relates to the flattening of organizational structures, characteristic for effective information age businesses. Accordingly, it is proposed that we reconsider the separation between officers and enlisted personnel.

A common theme throughout the book is change management. To sustain effective military in the information age, the leadership of the armed forces should have the intellectual, psychological, and organizational capacity and the will to anticipate, plan and implement change; on a permanent basis. An alternative driver for change would be battlefield defeat. With this thought provoking book Steven Metz argues that it is possible visionary leadership rather than blood to inspire necessary changes. 